\title{
THE IMPACT OF PSYCHO-EDUCATION ON IN VITRO FERTILISATION TREATMENT EFFICIENCY
}

\section{Jana Belevska}

Clinical hospital "Acibadem Sistina", Skopje, R. Macedonia

Corresponding Author: Jana Belevska, Bul. JNA 15-2/9, 1000 Skopje, R Macedonia; E-mail: janabelevska@ hotmail.com

\begin{abstract}
Aim: The aim of the study was to examine the efficiency of psycho-education of candidates for the IVF in stress, anxiety and depression decreasing, and the impact of the psycho educative techniques on the successfulness of the treatment.

Method: A random sample of 64 candidates for IVF treatment is divided in two groups: control group without psycho-education (32 candidates) and intervention group of 32 candidates included in psycho-education. Depression, anxiety and stress scale (DASS) was used as a psychometric test. It's a multiple choice, self-reported inventory for measuring the levels of stress, anxiety and severity of depression.

For statistic evaluation SPSS software was used.

Results: The study shows that the intervention group included in psycho-education has a signifycantly lower scores on stress $(\mathrm{t}=3.201, \mathrm{p}<0.05)$ and anxiety $(\mathrm{t}=2.311, \mathrm{p}<0.05)$. The scale of depression did not show differences in the two compared groups. However, the success of the IVF treatment is more common among candidates that were included in psycho-education.

Conclusion: In our country, psycho-education of candidates for in vitro fertilization is not systematically integrated in the treatment. The study showed the efficiency of psycho-education in anxiety and stress decreasing, as well as significant impact in the successfulness of the treatment.

It was pointed out that psychological support of candidates for IVF is important for the lessening of the negative emotional reactions of candidates as well as for the successfulness of the treatment.
\end{abstract}

Key words: IVF treatment, stress, anxiety, depression, psycho-educational counseling

\section{Introduction}

Involuntary childlessness is psychologycally recognized as a life crisis that has the potential to threaten the stability of individuals, relationships, and communities [1]. Forming a family is the most important life event for the couples, it's planned precisely in details: as education or career, so infertility is perceived or experienced as an insolvable problem threatening important life goals, taxing personal resources, and potentially arousing unresolved problems from the past. This is painful and devastating experience for the partners, man and woman, and their reactions are affected by perso- nal expectations, culture and social surrounding. The strong wish for children and consecutive reactions toward infertility are defined by our culture through complexity of personal, family, social and medical expectations that overcome sex, age, religion, ethnicity and social and economic class [2]. The stress of the non-fulfillment of parenthood role is associated with emotional sequela such as anger, depression, anxiety, marital problems and feelings of worthlessness. Partners may become more anxious to conceive, ironically increasing the sexual dysfunction and social isolation. In vitro fertilization (IVF) gives hope to the couples who wish 
to conceive, but making this medical decision is followed by pressure. Couples experience stigma, sense of loss and diminished self-esteem in the setting of their infertility [3].

Infertility of one or both of the partners is a serious problem that causes emotional reactions as anger, quilt, stress, depression, and each of them have negative impact on the successfulness of the IVF treatment [4]. Also, treatment failure appears to be associated with this emotional reaction $[5,6]$. It has been suggested that elevated anxiety and depression may cause lower pregnancy rates [7]. Most authors agree that fertility clinics should not only address the medical needs of their patients, but also their emotional needs. Boivin et al. [8,9] advocate that psycho-social counseling should be available during all stages of the IVF treatment. Psychological counseling can be distinguished in the context of infertility treatment: information gathering and analysis, implications and decisionmaking counseling, support counseling and therapeutic counseling. Psycho-education may help patients to collect and to comprehend all the information that is necessary to make treatment related decisions, as well as the emotional and social implications of these decisions (e.g. implications and decision-making counseling). Infertility psycho-education helps patients to explore, understand and cope with issues related to infertility and its treatment. When the IVF treatment is causing emotional distress in patients, counselors can offer them emotional support to help them cope more effectively with the treatment strain (e.g. support counseling). Therapeutic counseling or psychotherapy can be offered when specific issues concerning infertility or treatment need more working through.

In light of all the data suggesting that emotional reaction may interfere with fertility, success and birth rates of infertility treatment stimulated this study. Numerous similar studies are conducted worldwide, but that is not the case with regard to our country. The aim of this study was to examine the impact of the psychoeducation on the decreasing of stress, anxiety and depression in candidates for the IVF treatment, and to explore how the psycho-education at the beginning of the treatment affects the successfulness of the IVF treatment.

\section{Method and sample}

The examined candidates were recruited from the Clinical hospital "Acibadem Sistina" Skopje. The sample comprised 64 randomly selected women, candidates for IVF treatment, divided in two groups: control group without psycho-education (32 candidates) and intervention group of 32 candidates included in the psycho-education. An inclusion criterion for the study was infertility - primary or secondary. The psychometric instrument used for evaluation of stress, anxiety and depression was DASS (Depression, Anxiety, Stress Scale) scale.

DASS scale is a multiple choices, selfreported inventory for measuring negative emotional reactions of depression, anxiety and stress. DASS is designed not only as a scale to measure the conventionally defined emotional conditions, but also to lead the process of defining, understanding and measuring the omnipresent and clinically significant emotional states usually described as depression, anxiety and stress. Thus, the DASS should successfully meet the demands of researches and professional clinicians.

DASS is a 42-item questionnaire which includes three self-report scales designed to measure the negative emotional states of depression, anxiety and stress. Each of the three scales contains 14 items, divided into sub-scales of 2-5 items with similar content. The Depression scale assesses dysphoria, hopelessness, devaluation of life, self-deprecation, lack of interest/involvement, anhedonia, and inertia. The Anxiety scale assesses autonomic arousal, skeletal muscle effects, situation anxiety, and subjective experience of anxious affect. The Stress scale (items) is sensitive to levels of chronic non-specific arousal. It assesses difficulty of relaxing, being easily upset/agitated, irritable/overreactive and impatient. Respondents are asked to use 4-point severity/frequency scales to rate the extent to which they have experienced each state over the past week [10]. Total scores for depression, anxiety and stress are calculated by summing the scores from the relevant items. The data of fertility were obtained with protocol of semi structured interview with patients, as well as demographic data that relate to the relevant variables (year of birth, place of birth, education, occupation, marital status, nationality). Both instruments were applied at the beginning of the IVF treatment. 
The psycho-education, organized in onehour session, was conducted in the Center for counseling and psychotherapy "PhD. Diana Belevska" by clinical psychologist at the beginning of the IFV treatment.

\section{Results}

Study results determine that psycho-education of candidates for IVF can reduce the impact of stress and anxiety during IVF treatment and contribute to a bigger pregnancy rate.

The results show that the intervention group that was included in the psycho-education has statistically significant lower scores on stress $(\mathrm{t}=3.201, \mathrm{p}<0.05)$ and anxiety $(\mathrm{t}=2.311$, $\mathrm{p}<0.05)$. The scale of depression does not show statistically significant differences in the two compared groups.

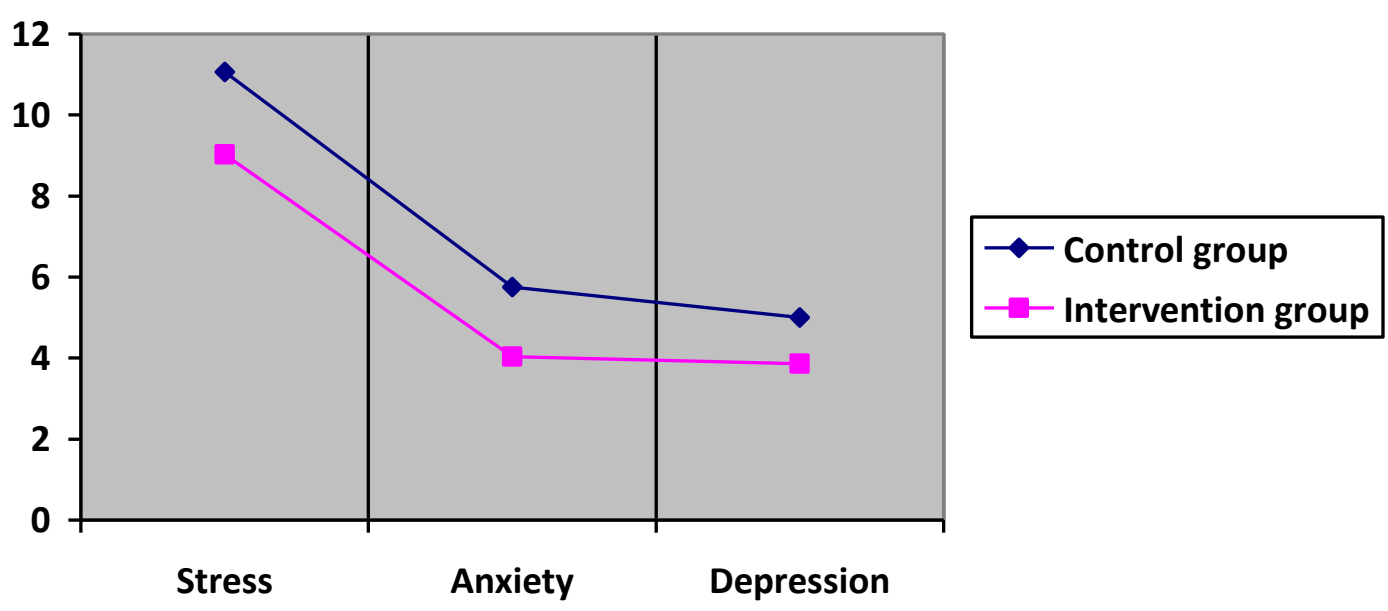

Figure 1 - Scores on DASS for both groups

Using multiple tables and Chi square it is determined that pregnancy rate in the intervention group is statistically higher than the pregnancy rate in the control group. (Table 1)

\section{Table 1}

Pregnancy rate

\begin{tabular}{|l|c|c|c|c|}
\hline \multicolumn{2}{|c|}{} & \multicolumn{2}{|c|}{ Pregnant } & \multirow{2}{*}{ Total } \\
\cline { 3 - 5 } \multicolumn{2}{|c|}{} & Yes & No & \\
\hline Psychological & Yes & 22 & 10 & 32 \\
\cline { 2 - 5 } counseling & NO & 15 & 17 & 32 \\
\hline Total & 37 & 27 & 64 \\
\hline
\end{tabular}

$$
\chi^{2}=4.625 \quad \mathrm{df}=1, \mathrm{p}<0.05
$$

Study results confirm that psycho-education used at the beginning of the treatment with IVF has positive impact. The success of the treatment with IVF is more common among candidates that were included in psycho-education. It can be seen from the Table 1 that out of 32 candidates from the intervention group with provided psycho-education at the beginning of the treatment with IVF 22 are pregnant, and from the control group out of 32 candidates who have been exposed to treatment with IVF without psycho-education, only 15 are pregnant.

In relation to the level of stress, anxiety and depression, candidates from the intervention group who were undergoing psycho-education, have lower middle scores than the middle scores of the candidates from control group without psycho-education. This confirms the impact of the psychological psycho-education on reducing stress, anxiety and depression and improved successfulness of the treatment with IVF.

\section{Discussion}

The psychological impact of infertility is widely confirmed. It implies great stress, depression, anxiety on the partners, reflects the relations and also provokes a crisis that threatens the self-image and identity. The most often reported psychological problems are: frustrations, anger and guilt, then, lowering of the self-perception, interpersonal difficulties, anxiety and depression. Even though assisted reproductive 
techniques give hope to those couples who wish to conceive, it has been detected that these medical interventions are particularly stressful experiences, especially for women [11]. The results of the quantitative research show that women who are about to start IVF may be more anxious than the control populations [12-14]. Negative emotions seem to disappear after IVF pregnancy, which could suggest that the depression related to IVF treatment results from the inability to become pregnant rather than the treatment itself [15]. On the other hand, the excitement and happiness associated with pregnancy may neutralize the negative treatment related emotions. Predisposition towards anxiety, pre-IVF depressive symptoms, personal characteristics, social support, pretreatment meaning of the fertility problem and expectations from the IVF are detected to be the most important predictors of emotional response to unsuccessful IVF treatment $[16,17]$. The importance of psycho-social factors is obvious. Denmark study confirms that using only the formal medical strategy of IVF treatment and not talking about the emotional aspects of infertility and its treatment suggested high fertility stress problem [18]. The same study shows that active avoidance of coping strategy and difficult partner communications as predictors to high infertility related stress are possible to be resolved if IVF candidates are psychologically supported to change their communication with the partner and other people close to them and that they achieved an increased awareness of what, how much and when to discuss with others [18].

Our study aimed to evaluate the possible impact of the psycho-education on candidates undergoing the IVF treatment on stress, anxiety and depression level as well as on the pregnancy rate. Psycho-education consist of one session with the candidate for IVF (single or couple) with clinical psychologist at the beginning of the IVF treatment to directly help candidates to explore, understand and cope with issues related to infertility and its treatment.

In her systematic review Boivin tried to answer two questions that are close to our subject of interest: Do psycho-social interventions improve well-being? and 2. Do psycho-social interventions increase pregnancy rates? [19]. With regard to the first question the review showed that mixed results were obtained with anxiety and depression measures. Overall, the positive effects were observed more frequently on the measures of anxiety (8/13 analyses: $61.5 \%)$ than on the measures of depression (5/13 analyses: $38.4 \%$ ). Our study also confirms this finding that the level of anxiety was significantly lower in the intervention group and no differrences were found with regard to the depresssion. On the other hand, the review showed that from 8 analyzed studies (chosen as good studies out of 15), three studies showed a positive intervention effect on pregnancy, whereas five studies showed no intervention effect. Based on the statistical measurements, considering the fact that because the effect size gives the strength of the intervention effect independent of the sample size, the effect sizes can be compared across studies. As with any other correlation, higher values indicated a stronger effect. The average effect size across the positive effect studies was significantly higher compared to the no effect studies. So, it seems clear that more research needs to be devoted to the systematic evaluation of the impact of psycho-social intervention on pregnancy rates. Our study confirms the effect of psycho-education over pregnancy rates. In a critical appraisal study of implications of psycho-social support in infertility it is confirmed that almost all psycho-social interventions showed positive effects on at least one of the outcome variables assessed, and none of the studies reported a negative effect on the wellbeing. The most effective are the psychological counseling and the support groups [20]. Therefore, infertility counseling should be available at all stages of the IVF treatment. Course, content and goals of the infertility counseling should be made transparent.

\section{Conclusions}

It is widely recognized that infertility implies great stress, depression and anxiety over partners. The IVF treatment gives hope to the couples, but treatment failure seems to be associated with these negative emotional reactions. The role of the psychological factors in the IVF treatment efficiency is obvious, so fertility clinics should not only address the medical needs of their patients, but also their emotional needs. Our study confirms that psycho-education used 
at the beginning of the treatment with IVF is efficient in both, reducing stress and anxiety and increasing the clinical pregnancy rates. Infertility psycho-education helps patients explore, understand and cope with issues related to infertility and its treatment, which helps to decrease negative emotional reactions and improves the IVF treatment efficiency.

\section{REFERENCES}

1. Burns HL, Covington NS. Psychology of infertility. Infertility Counseling. A Comprehensive Handbook for Clinicians, Second Edition. Cambridge University Press. 2006

2. Whiteford LM, Gonzalez L. Stigma. The hidden burdens of infertility. Social Science Medicine. 1995; No. 40(4): 27-36.

3. Kumar Deka P, Sarma S. Psychological aspects of infertility. BJMP. 2010; No. 3(3): a336.

4. Smeenk JM, Verhaak CM, Braat DD. Psychological interference in in vitro fertilization treatment. Fertil Steril. 2004; 81(2): 277.

5. Sanders KA, Bruce NW. Psychological stress and treatment outcome following assisted reproductive technology. Human reproduction. 1999; 14(6): 1656-62.

6. Newton CR, Hearn MT, Yuzpe AA. Psychological assessment and follow-up after in vitro fertilization: assessing the impact of failure. Fertil Steril. 1990; 54(5): 879-86.

7. Smeenk JM, Verhaak CM, Eugster A, van Minnen A, Zielhuis GA, Braat DD. The effect of anxiety and depression on the outcome of in-vitro fertilization. Hum Reprod. 2001; 16(7): 1420-3.

8. Boivin $\mathbf{J}$, et al. Guidelines for counseling in infertility: outline version. Hum Reprod. 2001; 16(6): 1301-4.

9. Boivin J. A review of psychosocial interventions in infertility. Soc Sci Med. 2003; 57(12): 2325-41.

10. Lovibond SH, Lovibond PF. Manual for the Depression anxiety Stress Scales. (2nd Ed) Sydney: Psychology Foundation. 1995. Hum Reprod. 1999; 14(12): 3126-32.

11. Ardent R. et al. Anxiety and perceptive functioning of infertile women during in vitro fertilization: exploratory survey of an Italian sample.

12. Mori E, Nadaoka T, Morioka Y, Saito H. Anxiety of infertile women undergoing IVF-ET: relation to the grief process. Gynecol Obstet Invest. 1997; 44(3): 157-62.

13. Slade P, Emery J, Lieberman BA. A prospective, longitudinal study of emotions and relationships in in-vitro fertilization treatment. Hum Reprod. 1997 Jan; 12(1): 183-90.

14. Salvatore P, Gariboldi S, Offidani A, Coppola F, Amore M, Maggini C. Psychopathology, personality, and marital relationship in patients undergoing in vitro fertilization procedures. Fertil Steril. 2001 Jun; 75(6): 1119-25.
15. Verhaak CM, Smeenk JM, Evers AW, Kremer JA, Kraaimaat FW, Braat DD. Women's emotional adjustment to IVF: a systematic review of 25 years of research. Hum Reprod Update. 2007; 13(1): 27-36.

16. Newton CR, Hearn MT, Yuzpe AA. Psychological assessment and follow-up after in vitro fertilization: assessing the impact of failure. Fertil Steril. 1990; 54(5): 879-86.

17. Verhaak CM, Smeenk JM, van Minnen A, Kremer JA, Kraaimaat FW. A longitudinal, prospective study on emotional adjustment before, during and after consecutive fertility treatment cycles. Hum Reprod. 2005; 20(8): 2253-60.

18. Schmidt L. Infertility and assisted reproduction in Denmark. Epidemiology and psychosocial conesquences. Den Med Bull. 2006: 53(4)390-417.

19. Boivin J. A review of psychosocial interventions in infertility. Soc Sci Med. 2003; 57: 2325-2341.

20. Wischmann T. Implications of psychosocial support in infertility - a critical appraisal. Journal of Psychosomatic Obstetrics \& Gynecology. 2008; 29(2): 83-90.

Резиме

\section{ВЛИЈАНИЕТО НА ПСИХОЕДУКАЦИЈАТА ВРЗ ЕФИКАСНОСТА НА ИН ВИТРО ФЕРТИЛИЗАЦИЈАТА}

\section{Јана Белевска}

Клиничка болница „Аџибадем Систина“, Скопје, Р. Македонија

Цел: Целта на студијата е да се добијат сознанија во врска со влијанието на психоедукативните интервенции врз намалување на стресот, анксиозноста и депресивноста кај кандидатите за третман со ин витро фертилизација и колку овие интервенции преземени пред почетокот на третманот влијаат врз неговата успешност.

Matеријал и меtogu: Со студијата е опфатен примерок избран со рандомизација од 64 испитаници поделени во две групи: испитувана група која е составена од 32 испитаници кои се вклучени во психоедукација и контролна група од 32 испитаници без психоедукација.

Како психометриски инструмент е користена ДАС-скала. ДАС-скалата е саморепортирачки инструмент што мери анксиозност, стрес и депресија.

За статистичка обработка на податоците е користен пакетот SPSS.

Резул та и: Испитуваната група кај која беа спроведени психоедукативни интервенции покажа статистички значајно пониски скорови на стрес $(\mathrm{t}=3,201, \mathrm{p}<0,05)$ и анксиозност $(\mathrm{t}=2,311, \mathrm{p}<$ 
0,05). Не се забележани промени во однос на скалата на депресивност. Ефикасноста на ин витро фертилизацијата е повисока кај кандидатките вклучени во психоедукација.

Заклучок: Во рамките на нашата земја психолошкото советување не е интегрален дел на ин витро третманот. Студијата го потврди значењето на психоедукацијата во редукција на стресот и анксиозноста и во зголемување на ефикасноста на третманот.
Истакнато е дека психолошката поддршка на кандидатите за ин витро фертилизација е важна за намалување на негативните емоционални доживувања на кандидатите и за зголемување на ефикасноста на третманот.

Клучни зборови: третман на кандидати за ин витро фертилизација, стрес, анксиозност, депресивност, психоедукација 